\title{
stuons IBERO-AMERICANOS
}

\section{Revista Estudos Ibero-Americanos - v. 44, n. 3, 2018 \\ Estudos Ibero-Americanos (Ibero-American Studies) Review - v. 44, n. 3, 2018 Revista Estudos Ibero-Americanos (Estudios Iberoamericanos) - v. 44, n. 3, 2018}

Neste terceiro número do volume 44 do ano de 2018, a revista Estudos Ibero-Americanos traz o dossiê "Cores, Classificações e categorias sociais: os Africanos nos impérios ibéricos, séculos XVI a XIX, organizado pelas professoras Eugénia Rodrigues (Centro de História da Universidade de Lisboa, Portugal) e Mariana P. Candido (University of Notre Dame, Estados Unidos da América), dedicado ao amplo período de construção e consolidação dos impérios ibéricos que colocaram em diálogo povos de diferentes origens e etnias sob a égide colonial. As múltiplas formas de dominação e resistência, com a construção inclusive de um vocabulário específico, atravessou os campos econômico, político, cultural e social, marcando o cotidiano dos povos nas Américas, na África e na Europa. Este dossiê é composto de oito artigos de pesquisadores brasileiros e estrangeiros elaborados a partir de diferentes recortes temáticos e suportes teóricos. Além dos artigos, o dossiê também é composto por uma resenha e uma entrevista. $\mathrm{O}$ reconhecimento internacional das organizadoras do Dossiê possibilitou que tivéssemos contribuições de autores de diferentes instituições no Brasil e no exterior, qualificando o dossiê aqui apresentado, a saber: Instituto Federal do Rio Grande do Sul, IFRS, Pontifícia Universidade Católica do Rio de Janeiro, PUC-Rio; Universidade Federal da Paraíba, UFPB; Universidade Estadual de Campinas, Unicamp; Universidade de Lisboa, Portugal; University of Toronto, Canadá; e, Universidad Nacional Autónoma de México. Agradecemos às professoras Eugénia Rodrigues e Mariana P. Candido pelo empenho e pela dedicação em todas as etapas que envolvem a publicação de um dossiê. A qualidade do trabalho delas pode ser verificada através da apresentação do dossiê que nos traz uma análise cuidadosa sobre o tema.
Neste número, também estamos publicando na Seção Livre quatro artigos de pesquisadores de diferentes IES, mantendo a diversidade nacional e a internacionalização que consagraram a Estudos Ibero-Americanos como uma referência na área (Pontifícia Universidade Católica do Rio Grande do Sul, PUCRS; Universidade Estadual Paulista, UNESP-ASSIS; Universidade Federal Fluminense, UFF; Universidade Salgado de Oliveira, UNIVERSO; Universidad Católica de Valparaíso, Chile).

Assim, nós finalizamos o último número do volume 44 editado este ano, reforçando nosso compromisso com a qualidade acadêmica, através da realização de avaliação cega pelos pares, da adoção dos critérios rigorosos na seleção dos artigos e do cumprimento das normas estabelecidas pela CAPES.

Os méritos de uma revista acadêmica são sempre o resultado de um trabalho coletivo. Por isso, não podemos deixar de agradecer à Equipe Editorial da EIA formada pelos seus editores, Conselho Editorial, Conselho Consultivo, Pós-Graduandos e Graduandos. À profa. Eleonor Gastal Lago e a Ádila Rejane Cunha de Castro, nosso agradecimento pelo apoio ao longo de todo o processo editorial. $\mathrm{O}$ empenho de todos e todas torna essa revista possível. Um agradecimento especial à doutoranda Letícia Sabina Wermeier Krilow, secretária-geral da EIA. Aos leitores e leitoras, desejamos uma ótima leitura!

$$
\begin{array}{r}
\text { Tatyana de Amaral Maia }{ }^{1} \\
\text { Editora }^{\text {Mura }} \\
\text { Luciana Murari }{ }^{1} \\
\text { Editora executiva }
\end{array}
$$

